\title{
Prevalence of Polyomaviruses in Polish patients
}

\author{
Marzena Badura, Jakub Dworzanski, Anna Polz, Malgorzata Polz-Dacewicz
}

Department of Virology, Medical University of Lublin, 1 Chodzki, 20-093 Lublin, Poland

\section{ARTICLE INFO}

Received 21 October 2014

Accepted 08 December 2014

\section{Keywords:}

Polyomaviruses KI and WU,

respiratory tract,

co-infection.

\begin{abstract}
The aim of our study was to investigate the prevalence of new polyomaviruses KIPyV and WUPyV in the Polish population in the Lublin region. In it, we demonstrated that the prevalence of this viruses is low $-1.1 \% \mathrm{WU}$ and $3.4 \% \mathrm{KI}$. The viruses are most commonly detected in materials from the respiratory tract, both in children and the elderly. Polyomaviruses KI and WU in co-infection, often occur with other respiratory viruses (influenza, enterovirus).
\end{abstract}

\section{INTRODUCTION}

Polyomaviruses are small (40-45 $\mathrm{nm}$ in diameter), nonenveloped double-stranded DNA viruses widely distributed in the human population $(1,4,11,14)$. The human polyomavirus (HPyV) belongs to the Polyomaviridae family, which consists of ten members. Human polyomavirus KI (KIPyV) was isolated in 2007, during the screening of human respiratory tract samples. In the same year, another group of scientists, led by Gaynour (5), detected WU virus (WUPyV) in a nasopharyngeal aspirate from a 3-year-old child from Australia who was diagnosed with pneumonia.

The analysis of the DNA sequence indicated that the WU genome size is 5229 bp and 5040 bp for KI. The genome organization included an early gene region coding the large T-antigen (LTag) and the small T-antigen (sTag); a late gene region coding the capsid proteins VP1, VP2 and VP3; and the non-coding control region (NCCR) which regulates the expression of the viral early and late genes. The prevalence in healthy individuals varied from $0.5-5 \%$ for KIPyV and $0.4-9 \%$ for WUPyV, and it increased in immunosuppressed individuals (4).

The aim of our study was to analyze the prevalence of new polyomaviruses (KIV and WUV) in the Polish population. The results were analyzed according to the clinical material, sex, age and presence of co-infection.

\section{MATERIALS AND METHODS}

The study involved a total of 88 samples from the respiratory tract (saliva, BAL and nasopharynx swabs). All samples were tested for the presence of KI and WU polyomaviruses from different groups of patients. The first group consisted of 13 samples of saliva from healthy dental students

\section{Corresponding author}

e-mail:m.polz@umlub.pl of the Medical University of Lublin. The second studied population included 10 patients hospitalized in the pneumology ward of SPSK4 in Lublin, who were diagnosed with lung cancer (the material was BAL). The largest group consisted of 65 patients (54\% women and $46 \%$ men) diagnosed in the direction of being affected with an influenza virus infection, from whom nasopharynx swabs were obtained. In this group, there were 40 samples taken during the 2009/2010 epidemic season, from children under the age of 18 (23 girls and 17 boys) who were hospitalized in the Hematology Ward and the Department of Pulmonary Diseases, of the Children's Hospital in Lublin, while 25 samples were from patients diagnosed in Lublin hospitals and in the Lublin region during the 2012/2013 epidemic season (12 women and 13 men; average age 41 years).

To detect the DNA of the new polyomaviruses KI and WU, the primers described by Bialasiewicz and co-workers (3) were used. Table 1 presents the primers used for the detection of WUV and KIV. The PCR reaction was performed in a thermocycler LabCycler (SensoQuest Company). The PCR products were detected by electrophoresis in a $2 \%$ agarose gel. The size of the product for each PCR reaction was: KIA - 95 bp, KIB - 114 bp, WUB - 136 bp.

Table 1. Primers used for the detection of WUV and KIV in a PCR reaction

\begin{tabular}{|c|c|c|}
\hline $\begin{array}{l}\text { Starter } \\
\text { Name }\end{array}$ & Sequence & $\begin{array}{l}\text { The complementary } \\
\text { region of the viral } \\
\text { genome }\end{array}$ \\
\hline \begin{tabular}{|c|}
$\mathrm{KI}-\mathrm{A}$ \\
Forward
\end{tabular} & $5^{\prime}$ - ACCTGATACCGGCGGAACT - 3' & \multirow{2}{*}{ regulatory region } \\
\hline $\begin{array}{c}\mathrm{KI}-\mathrm{A} \\
\text { Reverse }\end{array}$ & $5^{\prime}-$ CGCAGGAAGCTGGCTCAC - 3' & \\
\hline \begin{tabular}{|c|} 
KI-B \\
Forward
\end{tabular} & 5' - GAATGCATTGGCATTCGTGA - 3' & \multirow{2}{*}{ small $\mathrm{T}$ antigen } \\
\hline $\begin{array}{c}\text { KI-B } \\
\text { Reverse }\end{array}$ & 5' - GCTGCAATAAGTTTAGATTAGTTGGTGC - 3' & \\
\hline $\begin{array}{c}\text { WU-B } \\
\text { Forward }\end{array}$ & 5' - CTACTGTAAATTGATCTATTGCAACTCCTA - 3 & \multirow{2}{*}{ large $\mathrm{T}$ antigen } \\
\hline $\begin{array}{c}\text { WU-B } \\
\text { Reverse }\end{array}$ & 5' - GGGCCTATAAACAGTGGTAAAACAACT - 3' & \\
\hline
\end{tabular}




\section{RESULTS}

Among the tested 88 samples, polyomaviruses were detected only in 4 (4.5\%). The results obtained are shown in Tables 2 and 3. The DNA of the new polyomaviruses was detected exclusively in nasopharynx swabs, i.e. in 3 cases, the $\mathrm{KI}$ virus and in 1 case, the WU virus.

Table 2. Distribution of infection polyomaviruses KI, WU in different materials

\begin{tabular}{|c|c|c|c|c|}
\hline \multirow{2}{*}{$\begin{array}{c}\text { Material } \\
\text { Test }\end{array}$} & \multicolumn{2}{|c|}{ KIV } & \multicolumn{2}{c|}{ WUV } \\
\cline { 2 - 5 } & $\begin{array}{c}\text { positive } \\
(\%)\end{array}$ & $\begin{array}{c}\text { negative } \\
(\%)\end{array}$ & $\begin{array}{c}\text { positive } \\
(\%)\end{array}$ & $\begin{array}{c}\text { negative } \\
(\%)\end{array}$ \\
\hline Saliva & 0 & 13 & 0 & 13 \\
$\mathrm{~N}=13$ & $(0 \%)$ & $(100 \%)$ & $(0 \%)$ & $(100 \%)$ \\
\hline $\mathrm{BAL}$ & 0 & 10 & 0 & 10 \\
$\mathrm{~N}=10$ & $(0 \%)$ & $(100 \%)$ & $(0 \%)$ & $(100 \%)$ \\
\hline $\begin{array}{c}\text { nasopharyngeal } \\
\text { swabs }\end{array}$ & 3 & 62 & 1 & 64 \\
$\mathrm{~N}=65$ & $(4.6 \%)$ & $(95.4 \%)$ & $(1.5 \%)$ & $(98.5)$ \\
\hline
\end{tabular}

Table 3. Distribution of the results of infections with polyomaviruses KI and WU in nasopharynx swab specimens, according to sex, age and presence of co-infection with the influenza virus

\begin{tabular}{|c|c|c|c|c|c|}
\hline & \multicolumn{2}{|c|}{ KIV } & \multicolumn{2}{|c|}{ WUV } \\
\hline & & $\begin{array}{c}\text { positive } \\
(\%)\end{array}$ & $\begin{array}{l}\text { Negative } \\
(\%)\end{array}$ & $\begin{array}{c}\text { positive } \\
(\%)\end{array}$ & $\begin{array}{c}\text { negative } \\
(\%)\end{array}$ \\
\hline \multirow[b]{2}{*}{ Sex } & $F(N=35)$ & $\begin{array}{c}2 \\
(5.7 \%)\end{array}$ & $\begin{array}{c}33 \\
(94.3 \%) \\
\end{array}$ & $\begin{array}{c}1 \\
(2.9 \%)\end{array}$ & $\begin{array}{c}34 \\
(97.1 \%)\end{array}$ \\
\hline & $M(N=30)$ & $\begin{array}{c}1 \\
(3.3 \%) \\
\end{array}$ & $\begin{array}{c}29 \\
(96.7 \%) \\
\end{array}$ & $\begin{array}{c}0 \\
(0 \%)\end{array}$ & $\begin{array}{c}30 \\
(100 \%)\end{array}$ \\
\hline \multirow{2}{*}{ Age } & $\begin{array}{c}<18 \\
(\mathrm{~N}=38)\end{array}$ & $\begin{array}{c}2 \\
(5.3 \%)\end{array}$ & $\begin{array}{c}36 \\
(94.7 \%)\end{array}$ & $\begin{array}{c}0 \\
(0 \%)\end{array}$ & $\begin{array}{c}38 \\
(100 \%)\end{array}$ \\
\hline & $\begin{array}{c}\geq 18 \\
(N=27)\end{array}$ & $\begin{array}{c}1 \\
(3.7 \%) \\
\end{array}$ & $\begin{array}{c}26 \\
(96.3 \%) \\
\end{array}$ & $\begin{array}{c}1 \\
(3.7 \%)\end{array}$ & $\begin{array}{c}26 \\
(96.3 \%) \\
\end{array}$ \\
\hline \multirow{2}{*}{$\begin{array}{l}\text { co-infection with } \\
\text { influenza }\end{array}$} & $\begin{array}{c}\text { Yes } \\
(\mathrm{N}=34)\end{array}$ & $\begin{array}{c}1 \\
(2.9 \%) \\
\end{array}$ & $\begin{array}{c}33 \\
(97.1 \%) \\
\end{array}$ & $\begin{array}{c}1 \\
(29 \%) \\
\end{array}$ & $\begin{array}{c}33 \\
(97.1 \%) \\
\end{array}$ \\
\hline & $\begin{array}{c}\text { No } \\
(\mathrm{N}=31)\end{array}$ & $\begin{array}{c}2 \\
(6.5 \%)\end{array}$ & $\begin{array}{c}29 \\
(93.5 \%)\end{array}$ & $\begin{array}{c}0 \\
(0 \%)\end{array}$ & $\begin{array}{c}31 \\
(100 \%)\end{array}$ \\
\hline
\end{tabular}

In the case of the nasopharynx swabs, positive results were more frequent in women (2- KIV and 1-WUV) than in men (1 KIV). Such positive results were obtained in 2 children under 18 years old and 2 adults. KIV was detected in a one-year-old girl, a ten-year-old boy as well as in several adult women.

Nasopharynx swab samples were obtained from patients diagnosed with influenza virus infections, and from hospital staff showing influenza-like symptoms or who were at risk for infection by contact with the patient. In the 2009/2010 season, two KIV infections were detected. In the 2012/2013 season, one KIV infection and one WUV infection was detected. In one case of KIV and WUV infection, there was a co-infection with influenza. In the case of co-infection, a WUV influenza virus occurred. The patient with the KIV infection was co-infected with two viruses - influenza and enterovirus.

In $12.3 \%$ of the patients who were nasopharynx swabbed, bone marrow was transplanted, but in this material, no DNA polyomaviruses were detected. All positive results were from immunocompetent patients (Table 4).

Table 4. Details of samples with KIV and WUV

\begin{tabular}{|c|c|c|c|c|c|}
\hline $\begin{array}{c}\text { Detected } \\
\text { polyomavirus }\end{array}$ & $\begin{array}{c}\text { Type of } \\
\text { sample }\end{array}$ & Age & Sex & Co-infection & $\begin{array}{c}\text { Immunological } \\
\text { State }\end{array}$ \\
\hline WUV & $\begin{array}{c}\text { nasopharynx } \\
\text { swab }\end{array}$ & 99 & $\mathrm{~F}$ & $\begin{array}{c}\text { influenza } \\
\text { virus }\end{array}$ & Immunocompetitive \\
\hline KIV & $\begin{array}{c}\text { nasopharynx } \\
\text { swab }\end{array}$ & 1 & $\mathrm{~F}$ & $\begin{array}{c}\text { influenza } \\
\text { virus, } \\
\text { enterovirus }\end{array}$ & immunocompetitive \\
\hline KIV & $\begin{array}{c}\text { nasopharynx } \\
\text { swab }\end{array}$ & 10 & $\mathrm{M}$ & - & immunocompetitive \\
\hline KIV & $\begin{array}{c}\text { nasopharynx } \\
\text { swab }\end{array}$ & $\geq 18$ & $\mathrm{~F}$ & - & immunocompetitive \\
\hline
\end{tabular}

\section{DISCUSSION}

Polyomaviruses are widespread throughout the world (11, 14), and it is estimated that most people have had contact with them. This notion is evidenced by a high rate of prevalence of anti-KIV, and anti-WUV, respectively, 55-90\%, $69-98 \%$, in the general population (4). Furthermore, high rates of indication were obtained in a study conducted in Australia, USA, South Korea, Thailand, France, in samples drawn from both children and adults (1).

In a previous study, Bialasiewicz et al. (2) surveyed the samples from the respiratory tract (nasopharynx swabs, BAL), blood, urine, stool and cerebrospinal fluid. This work showed that KIV and WUV were detected mainly in the aspirates from the respiratory system. Much more positive results were found in immunosuppressed patients. In our study, 2 /4 positive samples were from patients under 18 years of age.

Robaina et al. (13) demonstrated that the reactivation of primary infection with polyomaviruses also applies to immunocompetent persons. In saliva samples collected from people aged $15-75$ years, about $23.4 \%$ were positive for at least one polyomavirus, including $12.7 \% \mathrm{WU}$ and $2.4 \% \mathrm{KI}$. Infection was often observed in young people aged 15-19 $(46 \%)$ and in people over 50 years of age (33.3\%). In our study, no genetic material of polyomaviruses was found in the saliva samples taken from healthy students.

Frequency of detection of the genetic material is guided by the polyomaviruses primers. Bialasiewicz et al. $(2,3)$ obtained the best results using primers KI-A, WU-B, WU-C. Our results are similar.

New polyomaviruses infections are more frequent in childhood (7). Research carried out in the Netherlands shows that $95 \%$ of all WUV infection and $83 \%$ of all KIV infection occurred in children under 4 years of age, which may be related to they not having a fully developed immune system (15). Moureze et al. (10) showed that infection in adults is associated with immunosuppression. This is confirmed by our study in adults and children.

Infection with KIV and WUV is more frequently observed in patients with acute respiratory infection than in healthy subjects $(6,8,9)$. In our study, the genetic material of polyomavirus was detected in samples from individuals diagnosed with influenza virus or flu-like symptoms.

KIV and WUV are common in people with weakened immune systems. This was demonstrated while testing the nasal wash, trachea and bronchi of hematological and oncological patients, as well as people with normal immunity after ARI (12). In immunocompromised patients, higher KIV were also observed. On the other hand, in our study, all positive results were obtained only in the nasopharyngeal swabs of immunocompetent individuals.

Many studies point to the participation of these viruses in co-infections. Venter et. al. (16) showed that over $70 \%$ of the virus was detected in co-infection with WUV or $\mathrm{KIV}$, and more than $60 \%$ co-infections consist mainly of that with other respiratory viruses, as well as with bacteria (Pseudomonas aeurginosa). In our studies, positive results were obtained in patients infected with the influenza virus. In one patient infected with KIV, a virus co-infection with 
influenza and with enterovirus was found, in still another, the co-infection was only with the influenza virus.

Patients with KIV virus displayed flu-like symptoms and could also have been infected with other pathogens of the respiratory system. Our results are consistent with those reported in the literature, and they suggest the new polyomaviruses' affinity for the respiratory system. Further studies and standardized molecular virological diagnostics are, therefore, needed to define the pathogenic role of these two polyomaviruses in a specific disease.

\section{CONCLUSIONS}

1. The prevalence of these new polyomaviruses in Polish patients is low $-1.1 \% \mathrm{WUV}$ and $3.4 \% \mathrm{KIV}$.

2. Most commonly, the virus is detected in materials from the respiratory system of children and the elderly.

3. Polyomaviruses KIV and WUV often occur in co-infection with other respiratory viruses.

\section{REFERENCES}

1. Babakir-Mina M. et al.: The human polyomaviruses KI and WU: virological background and clinical implications. APMIS 121, 746, 2013.

2. Bialasiewicz S. et al. A newly reported human polyomavirus, KI virus, is present in the respiratory tract of the Australian population. J. Clin. Virol. 40, 15, 2007.

3. Bialasiewicz S. et al.: Development and evaluation of real-time PCR assays for the detection of the newly identified KI and WU polyomaviruses. J. Clin. Virol. 40, 9, 2007.
4. Dalianis T., Hirsch H.: Human polyomaviruses in disease and cancer. Virology 437, 63, 2013.

5. Gaynor A.M., Nissen M.D.: Identification of a novel polyomavirus from patients with acute respiratory tract infections. PLoSPathog. 3, 595, 2007.

6. He Han T. et al: WU Polyomavirus in children with acute lower respiratory tract infections., South Korea. Emerging Infectiuos Diseases 13, 1766, 2007.

7. Kiasari B.A. et. al.: Age-related pattern of KI and WU polyomavirus infection. J.Clin. Virol. 43, 123, 2008.

8. Li X. et al.: WUPyV in children with acute respiratory tract infections. China. Emerg. Infect. Dis. 16, 735, 2010.

9. Lin F. et. al: WU polyomavirus in children with acute lower respiratory tract infections. China J. Clin. Virol. 42, 94, 2008.

10. Mourez T. et al.: Polyomaviruses KI and WU in immunocompromised patients with respiratory disease. Emerging Infect. Dis. 15, 107, 2009.

11. Ngyyen N.L., Le B.M., Wang D.: Serologic evidence of frequent human infection with WU and KI polyomaviruses. Emerg., Infect. Dis. 2009, 15.

12. Rao S. et al.: WU and KI polyomavirus infections in pediatric hematology/oncology patients with acute respiratory tract illness. J. Clinical Virology 52, 28, 2011.

13. Robaina T.F. et al.: Shedding of polyomavirus in the saliva of immunocompetent individuals. J. Clin. Virol. 84, 144, 2013.

14. Świątek Ł., Polz-Dacewicz M.: Polyomaviruses as etiological agents of human diseases - a review. Viral infection and control. The role of viral infection in public health. UM, Pol. Tow. Wirusologiczne, Lublin 2010.

15. Van der Zalm M.M. et al.: Prevalence and pathogenicity of WU and KI polyomaviruses in children, the Netherlands. Emerg. Infect. Dis. $14,1788,2008$.

16. Venter M., Visser A., Lassauniere R.: Human Polyomaviruses WU and $\mathrm{KI}$ in HIV exposed children with acute lower respiratory tract infections in hospitals in South Africa. J. Clin. Virol. 44, 230, 2009. 